\title{
SEROLOGIC CHARACTERIZATION OF THE SOMATIC ANTIGENS OF E. coli STRAINS IN PIGLETS
}

SOUZA, C'.; WARTH, J.F.G'; BIESDORF, S.M.'; GONÇALVES, M.L.L.'; GOULART, M. ${ }^{2}$

${ }^{1}$ Departamento de Medicina Veterinária - UFPR;

${ }^{2}$ Secretaria da Agricultura e do Abastecimento - PR.

Colibacilosis is one the most important infectious diseases in swine farms causing diarrhea in piglets during neonatal and weanned period. The bacterial isolation and the serologic identification of the somatic antigens is very important, in order to make epidemiologic researches - as to know about spreading of a particular strain - and also permit includ these serotypes in the antigenic composition of autogenic or industrial vaccines against this disease, to be used in one specific region or farm. During a period of three years, 29 strains of $E$. coli were isolated of outbreaks of colibacilosis in Parana State and the serotype was identified.

The main serotypes were: 9 strains 0138:K81 (31\%); 8 strains 0141:K85a,b (27,5\%); 4 strains $0139: \mathrm{k} 82(13,8 \%) ; 3$ strains $0149: \mathrm{K} 91 \quad(10,3 \%) ;$ and 1 strain of 035:K"V79"(2,4\%); 0108:K"V189" (2,4\%);0115:K"V165"(2,4\%);0119:K"V113"(2,4\%); $0141: \mathrm{K} 85 \mathrm{a}, \mathrm{c}(2,4 \%)$ respectively. The fimbrial antigen F4 was present in $62,8 \%$ of strains and F165 in 14,3\%. This is the first report of the occurence of the fimbrial antigen named F165 in Brazil.

Key Words: Escherichia coli;diarrhea, piglets; serotyping. 